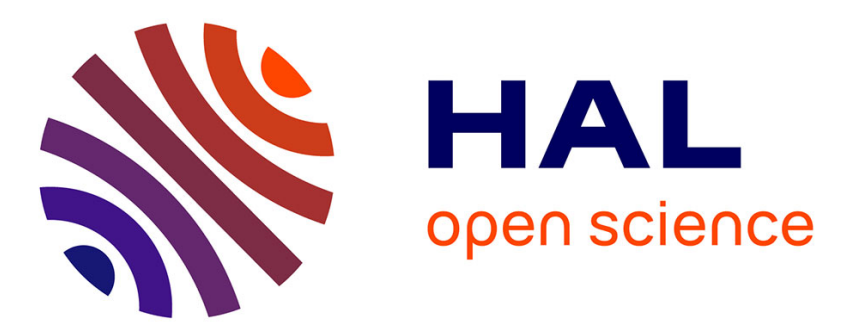

\title{
Synthesis and Crystal Structure of Two Cu II -benzene-1,2,4,5-tetracarboxylates with Three-Dimensional Open Frameworks
}

Roberto Köferstein, Christian Robl

\section{- To cite this version:}

Roberto Köferstein, Christian Robl. Synthesis and Crystal Structure of Two Cu II -benzene1,2,4,5-tetracarboxylates with Three-Dimensional Open Frameworks. Journal of Inorganic and General Chemistry / Zeitschrift für anorganische und allgemeine Chemie, 2014, 640 (2), pp.310-316. 10.1002/zaac.201300527 . hal-01986793

\section{HAL Id: hal-01986793 \\ https://hal.science/hal-01986793}

Submitted on 19 Jan 2019

HAL is a multi-disciplinary open access archive for the deposit and dissemination of scientific research documents, whether they are published or not. The documents may come from teaching and research institutions in France or abroad, or from public or private research centers.
L'archive ouverte pluridisciplinaire HAL, est destinée au dépôt et à la diffusion de documents scientifiques de niveau recherche, publiés ou non, émanant des établissements d'enseignement et de recherche français ou étrangers, des laboratoires publics ou privés. 


\section{Zeitschrift für anorganische und allgemeine Chemie}

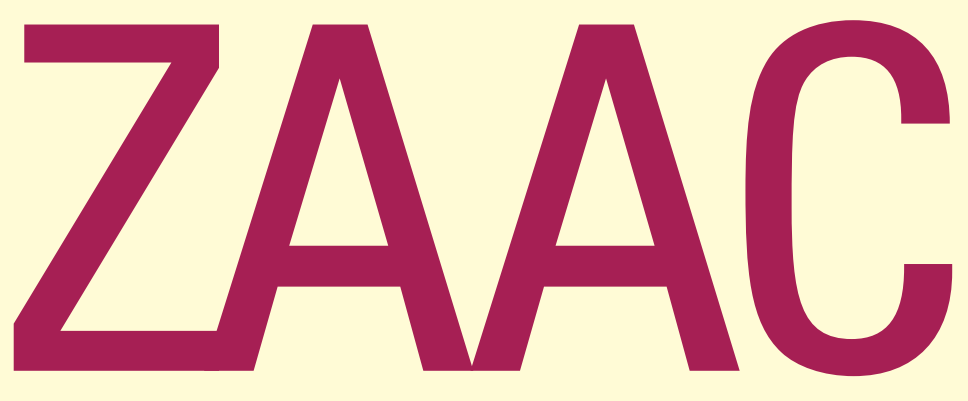

Journal of Inorganic and General Chemistry

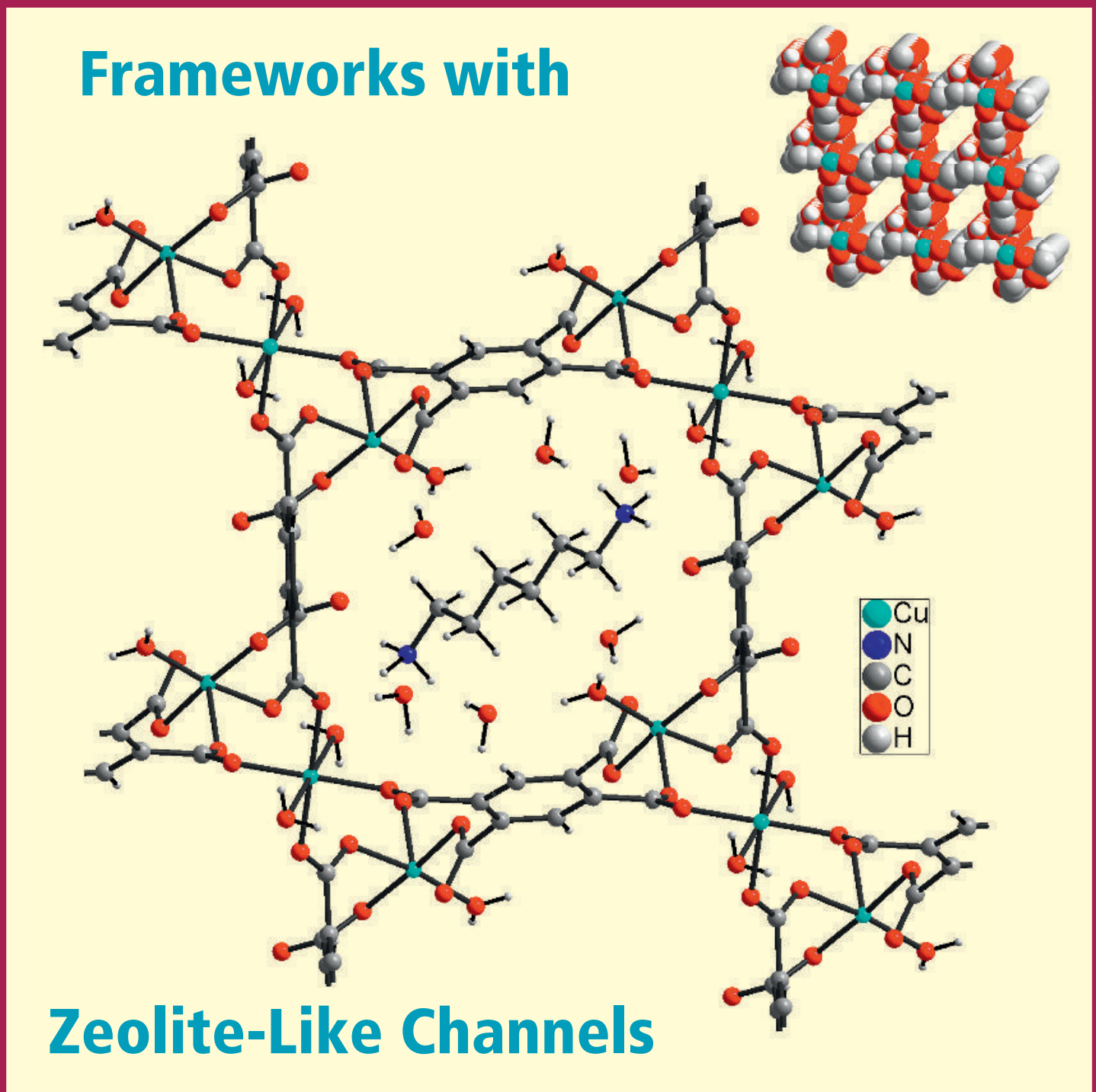

Cover Picture: Synthesis and Crystal Structure of Two Cu"-benzene-1,2,4,5tetracarboxylates with Three-Dimensional Open Frameworks Roberto Köferstein and Christian Robl 


\title{
Synthesis and Crystal Structure of two $\mathrm{Cu}$ (II)-benzene-1,2,4,5- tetracarboxylates with Three-Dimensional Open Frameworks
}

\author{
R. Köferstein and C. Robl
}

Z. Anorg. Allg. Chem. 640 (2014) 310-316

DOI: $10.1002 /$ zaac.201300527

\begin{abstract}
Two new three-dimensional frameworks with zeolite-like channels were prepared in the presence of 1,6-diaminohexane. $\mathrm{Cu}_{1.5}\left(\mathrm{H}_{3} \mathrm{~N}-\left(\mathrm{CH}_{2}\right)_{6}-\mathrm{NH}_{3}\right)_{0.5}\left[\mathrm{C}_{6} \mathrm{H}_{2}(\mathrm{COO})_{4}\right] \cdot 5 \mathrm{H}_{2} \mathrm{O}$ crystallizes in the triclinic space group $P \overline{1}$ with $a=772.56(7), b=1110.36(7), c=1111.98(8)$ pm, $\alpha=98.720(7)^{\circ}, \quad \beta=108.246(9)^{\circ}, \quad$ and $\gamma=95.559(7)^{\circ} . \mathrm{Cu}_{2}\left(\mathrm{H}_{3} \mathrm{~N}-\left(\mathrm{CH}_{2}\right)_{6}-\right.$ $\left.\mathrm{NH}_{3}\right)_{0.5}(\mathrm{OH})\left[\mathrm{C}_{6} \mathrm{H}_{2}(\mathrm{COO})_{4}\right] \cdot 3 \mathrm{H}_{2} \mathrm{O}(2)$ crystallizes in the monoclinic space group $P 2 / c$ with $a=$ 1159.34(11), $b=1059.44(7), c=1582.2(2) \mathrm{pm}$, and $\beta=106.130(11)^{\circ}$. The $\mathrm{Cu}^{2+}$ coordination polyhedra are connected by $\left[\mathrm{C}_{6} \mathrm{H}_{2}(\mathrm{COO})_{4}\right]^{4-}$ anions to yield three-dimensional frameworks with wide centrosymmetric channel-like voids. Complex 1 reveals voids extending along [100] with diagonals of $900 \mathrm{pm}$ and $300 \mathrm{pm}$, whereas in complex 2 the diagonal of the nearly rectangular crossection of the channels extending parallel to [001] is $900 \mathrm{pm}$. The negative excess charges of the frameworks are compensated by $\left[\mathrm{H}_{3} \mathrm{~N}-\left(\mathrm{CH}_{2}\right)_{6}-\mathrm{NH}_{3}\right]^{2+}$ cations, which occupy the voids along with water molecules. The $\left[\mathrm{H}_{3} \mathrm{~N}-\left(\mathrm{CH}_{2}\right)_{6}-\mathrm{NH}_{3}\right]^{2+}$ cations are not connected to $\mathrm{Cu}^{2+}$ and have served as templates.
\end{abstract}
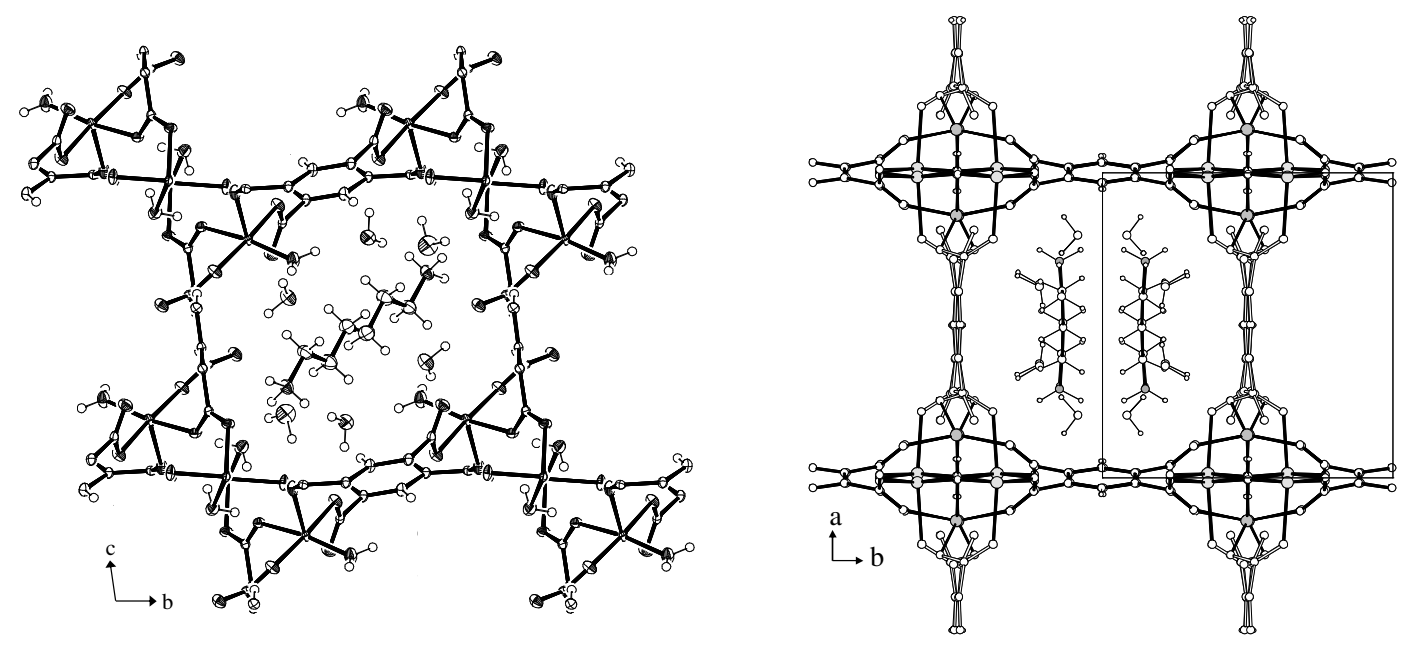


\title{
Synthesis and Crystal Structure of two Cu(II)-benzene-1,2,4,5-tetracarboxylates with Three-
}

\author{
Dimensional Open Frameworks
}

\author{
Roberto Köferstein $^{[\mathrm{a}, \mathrm{b}]}$ and Christian Robl ${ }^{*[a]}$
}

Keywords: Benzene-1,2,4,5-tetracarboxylate; Metal-organic-framework, Crystal structure; Template synthesis; Diaminohexane

\begin{tabular}{|c|c|}
\hline $\begin{array}{l}\text { Abstract. Two new three-dimensional frameworks with zeolite-like } \\
\text { channels have been prepared in the presence of 1,6-diaminohexane. } \\
\mathrm{Cu}_{1.5}\left(\mathrm{H}_{3} \mathrm{~N}-\left(\mathrm{CH}_{2}\right)_{6}-\mathrm{NH}_{3}\right)_{0.5}\left[\mathrm{C}_{6} \mathrm{H}_{2}(\mathrm{COO})_{4}\right] \cdot 5 \mathrm{H}_{2} \mathrm{O}(\mathbf{1}) \text { crystallizes in } \\
\text { the triclinic space group } P-1 \text { with } a=772.56(7), b=1110.36(7), c= \\
1111.98(8) \text { pm, } \alpha=98.720(7)^{\circ}, \beta=108.246(9)^{\circ} \text { and } \gamma= \\
95.559(7)^{\circ} . \mathrm{Cu}_{2}\left(\mathrm{H}_{3} \mathrm{~N}-\left(\mathrm{CH}_{2}\right)_{6}-\mathrm{NH}_{3}\right)_{0.5}(\mathrm{OH})\left[\mathrm{C}_{6} \mathrm{H}_{2}(\mathrm{COO})_{4}\right] \cdot 3 \mathrm{H}_{2} \mathrm{O}(\mathbf{2}) \\
\text { crystallizes in the monoclinic space group } P 2 / c \text { with } a= \\
1159.34(11), \quad b=1059.44(7), \quad c=1582.2(2) \text { pm and } \beta= \\
106.130(11)^{\circ} .\end{array}$ & $\begin{array}{l}\text { The } \mathrm{Cu}^{2+} \text { coordination polyhedra are connected by } \\
{\left[\mathrm{C}_{6} \mathrm{H}_{2}(\mathrm{COO})_{4}\right]^{4-} \text { anions to yield three-dimensional frameworks }} \\
\text { with wide centrosymmetric channel-like voids. Complex } 1 \\
\text { reveals voids extending along [100] with diagonals of } 900 \mathrm{pm} \\
\text { and } 300 \mathrm{pm} \text {, whereas in complex } 2 \text { the diagonal of the nearly } \\
\text { rectangular crossection of the channels extending parallel to } \\
{[001] \text { is } 900 \mathrm{pm} \text {. The negative excess charges of the frameworks }} \\
\text { are compensated by }\left[\mathrm{H}_{3} \mathrm{~N}-\left(\mathrm{CH}_{2}\right)_{6}-\mathrm{NH}_{3}\right]^{2+} \text {-cations, which occupy } \\
\text { the voids along with water molecules. The }\left[\mathrm{H}_{3} \mathrm{~N}-\left(\mathrm{CH}_{2}\right)_{6}-\mathrm{NH}_{3}\right]^{2+}- \\
\text { cations are not connected to } \mathrm{Cu}^{2+} \text { and have served as templates. }\end{array}$ \\
\hline
\end{tabular}

* Corresponding Author
Fax: +49-3641-948152
E-Mail: crr@uni-jena.de

[a] Institute of Inorganic and Analytical Chemistry, FriedrichSchiller-University Jena, Humboldtstrasse 8, 07743 Jena, Germany

[b] Institute of Chemistry, Inorganic Chemistry, Martin-LutherUniversity Halle-Wittenberg,

Kurt-Mothes-Strasse 2, 06120 Halle, Germany

\section{Introduction}

With multi-dentate complexing agents like the anions of benzenecarboxylic acids it is possible to form coordination polymers with various structural features [ $1-10]$. The carboxylate groups of benzenecarboxylic acids anions are able to coordinate metal ions in various modes, resulting in a plethora of interesting structures. Early reports have shown that the connection between the anions of benzene-1,2,4,5carboxylic acid (pyromellitic acid) and metal cations leads to coordination polymers with chain- and layer-like structures as well as to three-dimensional frameworks (socalled MOF's) [11-14]. The structures of coordination polymers can be varied using rational design synthesis e.g. $\mathrm{N}$-donor ligands as spacer and organic amines as template molecules, respectively [ $15-23]$. In particular, threedimensional frameworks are available in the presence of organic amines acting as template molecules [24-28]. Previous work on the reaction between $\mathrm{Cu}^{2+}$ and benzene1,2,4,5-carboxylic acid in the presence of templating agents resulted in various three-dimensional frameworks with channel-like voids resembling zeolite structures [29-35]. Additionally, $\mathrm{Cu}^{2+}$-benzenecarboxylato complexes can possess interesting magnetic properties $[21,30,31,33,35]$ and they can act as catalysts for e.g. peroxidative oxidation processes, for hydroxylation reactions, and for the reduction of nitrite $[32,36,37$,$] .$

Here we report on two new three-dimensional coordination polymers with wide channels as a result of the connection between $\mathrm{Cu}^{2+}$-cations and benzene-1,2,4,5tetracarboxylate anions in the presence of 1,6diaminohexane as template at two different temperatures of synthesis.

\section{Results and Discussion}

$\mathrm{Cu}_{1.5}\left(\mathrm{H}_{3} \mathrm{~N}-\left(\mathrm{CH}_{2}\right)_{6}-\mathrm{NH}_{3}\right)_{0.5}\left[\mathrm{C}_{6} \mathrm{H}_{2}(\mathrm{COO})_{4}\right] \cdot 5 \mathrm{H}_{2} \mathrm{O}$

There are two crystallographically independent $\mathrm{Cu}^{2+}$-ions. $\mathrm{Cu}(1)$ occupies the general position and $\mathrm{Cu}(2)$ a crystallographic inversion centre of space group P-1 (Wyckoff-position 1a). $\mathrm{Cu}(1)$ is coordinated by three 1,2,4,5-benzenetetracarboxylate oxygen atoms $(\mathrm{O}(2), \mathrm{O}(4)$, $\mathrm{O}(5), \mathrm{O}(8))$ and one water molecule $(\mathrm{O}(\mathrm{w} 1))$ forming a distorted square pyramid. $\mathrm{Cu}(2)$ is octahedrally coordinated by four oxygen atoms $(2 \mathrm{x} \mathrm{O}(1), 2 \mathrm{x} \mathrm{O}(6))$ stemming from the $1,2,4,5$-benzenetetracarboxylate-anion in the equatorial plane of the coordination octahedron and two water molecules $(2 \mathrm{x} \mathrm{O}(\mathrm{w} 2))$ in the apical positions (Fig. 1). The carboxylate groups of the $\left[\mathrm{C}_{6} \mathrm{H}_{2}(\mathrm{COO})_{4}\right]^{4-}$ anions coordinate the $\mathrm{Cu}^{2+}$-cations in a monodentate manner. The $\mathrm{Cu}-\mathrm{O}$ distances in the $\mathrm{Cu}(1)$ coordination polyhedron range from 192.6(2) to 240.0(2) pm, with the $\mathrm{Cu}(1)-\mathrm{OH}_{2}$ contact as the shortest bond. The $\mathrm{Cu}(2)$ polyhedron has $\mathrm{Cu}-\mathrm{O}$ bond lengths between 194.4(2) and 243.1(2) pm with the $\mathrm{Cu}(2)$ $\mathrm{OH}_{2}$ contact as the longest bond and in contrast to $\mathrm{Cu}(1)$ (Tab. 1). The bond order $(\mathrm{Cu}(1) 2.04 ; \mathrm{Cu}(2)$ 1.94) calculated by the method of Trömel $[38,39]$ is close to the expected values. 

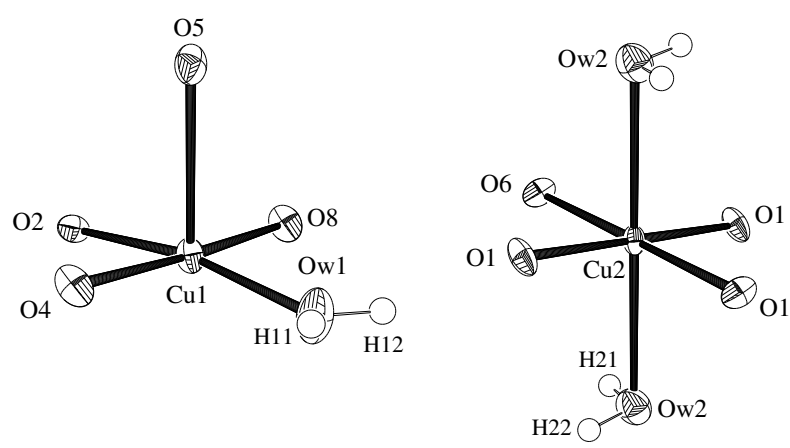

Figure 1. The coordination spheres of $\mathrm{Cu}(1)$ and $\mathrm{Cu}(2)$ in $\mathbf{1}(50 \%$ probability ellipsoids, arbitrary radii for hydrogen atoms).

Table 1. The Coordination of $\mathrm{Cu}^{2+}$ in $\mathrm{Cu}_{1.5}\left(\mathrm{H}_{3} \mathrm{~N}-\left(\mathrm{CH}_{2}\right)_{6}-\right.$ $\left.\mathrm{NH}_{3}\right)_{0.5}\left[\mathrm{C}_{6} \mathrm{H}_{2}(\mathrm{COO})_{4}\right] \cdot 5 \mathrm{H}_{2} \mathrm{O}(\mathbf{1})$

\begin{tabular}{lllr}
\hline \multicolumn{5}{l}{ bond lengths (pm) } & & \\
\hline $\mathrm{Cu}(1)-\mathrm{O}(\mathrm{w} 1)$ & $192.6(2)$ & $\mathrm{Cu}(2)-\mathrm{O}(6)$ & $194.4(2) 2 \mathrm{x}$ \\
$\mathrm{Cu}(1)-\mathrm{O}(8)$ & $196.0(2)$ & $\mathrm{Cu}(2)-\mathrm{O}(1)$ & $202.0(2) 2 \mathrm{x}$ \\
$\mathrm{Cu}(1)-\mathrm{O}(4)$ & $193.7(2)$ & $\mathrm{Cu}(2)-\mathrm{O}(\mathrm{w} 2)$ & $243.1(2) 2 \mathrm{x}$ \\
$\mathrm{Cu}(1)-\mathrm{O}(2)$ & $198.3(2)$ & & \\
$\mathrm{Cu}(1)-\mathrm{O}(5)$ & $240.0(2)$ & & \\
\hline bond angles $\left(^{\circ}\right)$ & & & \\
\hline $\mathrm{O}(\mathrm{w} 1)-\mathrm{Cu}(1)-\mathrm{O}(4)$ & $91.97(8)$ & $\mathrm{O}(6)^{\#}-\mathrm{Cu}(2)-\mathrm{O}(6)$ & 180 \\
$\mathrm{O}(\mathrm{w} 1)-\mathrm{Cu}(1)-\mathrm{O}(8)$ & $91.45(8)$ & $\mathrm{O}(6)^{\#}-\mathrm{Cu}(2)-\mathrm{O}(1)$ & $90.82(7)$ \\
$\mathrm{O}(4)-\mathrm{Cu}(1)-\mathrm{O}(8)$ & $176.42(7)$ & $\mathrm{O}(6)-\mathrm{Cu}(2)-\mathrm{O}(1)$ & $89.18(7)$ \\
$\mathrm{O}(\mathrm{w} 1)-\mathrm{Cu}(1)-\mathrm{O}(2)$ & $168.94(8)$ & $\mathrm{O}(1)-\mathrm{Cu}(2)-\mathrm{O}(1)^{\#}$ & 180 \\
$\mathrm{O}(4)-\mathrm{Cu}(1)-\mathrm{O}(2)$ & $87.66(7)$ & $\mathrm{O}(6)^{\#}-\mathrm{Cu}(2)-\mathrm{O}(\mathrm{w} 2)$ & $82.52(7)$ \\
$\mathrm{O}(8)-\mathrm{Cu}(1)-\mathrm{O}(2)$ & $89.18(7)$ & $\mathrm{O}(6)-\mathrm{Cu}(2)-\mathrm{O}(\mathrm{w} 2)$ & $97.49(7)$ \\
$\mathrm{O}(\mathrm{w} 1)-\mathrm{Cu}(1)-\mathrm{O}(5)$ & $96.28(8)$ & $\mathrm{O}(1)-\mathrm{Cu}(2)-\mathrm{O}(\mathrm{w} 2)$ & $86.03(7)$ \\
$\mathrm{O}(4)-\mathrm{Cu}(1)-\mathrm{O}(5)$ & $83.49(7)$ & $\mathrm{O}(1)-\mathrm{Cu}(2)-\mathrm{O}(\mathrm{w} 2)^{\#}$ & $93.97(7)$ \\
$\mathrm{O}(8)-\mathrm{Cu}(1)-\mathrm{O}(5)$ & $95.12(7)$ & $\mathrm{O}(\mathrm{w} 2)-\mathrm{Cu}(2)-\mathrm{O}(\mathrm{w} 2)^{\#}$ & 180 \\
$\mathrm{O}(2)-\mathrm{Cu}(1)-\mathrm{O}(5)$ & $94.66(6)$ & & \\
\hline
\end{tabular}

\#: -x;-y;-z

The two crystallographically independent $\left[\mathrm{C}_{6} \mathrm{H}_{2}(\mathrm{COO})_{4}\right]^{4-}$ anions (I, II) are located on an inversion centre (Fig. 2). Anion I is almost ideally planar with respect to the carbon atoms. The largest deviation from a plane fitted to the carbon skeleton is merely $1.6 \mathrm{pm}$ at $\mathrm{C}(5)$. The carboxylate groups are inclined to the $\mathrm{C}_{6}$ ring by $35.5^{\circ}(\mathrm{C}(7), \mathrm{O}(1)$, $\mathrm{O}(2))$ and $64.1^{\circ}(\mathrm{C}(8), \mathrm{O}(3), \mathrm{O}(4))$. Anion II is planar as well in good approximation. $\mathrm{C}(9)$ is $28.4 \mathrm{pm}$ out of the plane fitted to the carbon skeleton. The angle of torsion with respect to the $\mathrm{C}_{6}$ ring is $20.6^{\circ}(\mathrm{C}(12), \mathrm{O}(5), \mathrm{O}(6))$ and $41.8^{\circ}$ $(\mathrm{C} 13), \mathrm{O}(7), \mathrm{O}(8))$, respectively. The $\mathrm{C}-\mathrm{O}$ bond lengths of the anions range from 122.7(3) to 128.9(3). The oxygen atoms bound to $\mathrm{Cu}^{2+}$ form significant longer $\mathrm{C}-\mathrm{O}$ bonds than the others $(\mathrm{O}(3), \mathrm{O}(7))$ (Tab. 2). As shown in Fig. 3 the $\left[\mathrm{C}_{6} \mathrm{H}_{2}(\mathrm{COO})_{4}\right]^{4-}$ anion $\mathrm{I}$ is arranged parallel to the $(010)$ plane, whereas anion II is parallel to the (201) plane.
Table 2. Selected Bond Lengths (pm) and Angles $\left(^{\circ}\right)$ of the Benzene-1,2,4,5-tetracarboxylate-anions and the Hexane-1,6diammonium-cation in $\mathbf{1}$

\begin{tabular}{|c|c|c|c|}
\hline \multicolumn{4}{|l|}{ Anion I } \\
\hline$C(4)-C(6)$ & 139.4(3) & $\mathrm{C}(7)-\mathrm{O}(1)$ & $126.3(3)$ \\
\hline$C(4)-C(5)$ & $140.3(3)$ & $\mathrm{C}(7)-\mathrm{O}(2)$ & $126.4(3)$ \\
\hline$C(5)-C(6)$ & 139.4(3) & $\mathrm{C}(8)-\mathrm{O}(3)$ & $123.8(3)$ \\
\hline$C(4)-C(7)$ & $151.2(3)$ & $\mathrm{C}(8)-\mathrm{O}(4)$ & $127.0(3)$ \\
\hline $\mathrm{C}(5)-\mathrm{C}(8)$ & $151.9(3)$ & & \\
\hline$C(6)-C(4)-C(5)$ & $119.5(2)$ & $\mathrm{O}(2)-\mathrm{C}(7)-\mathrm{O}(1)$ & $123.0(2)$ \\
\hline $\mathrm{C}(6)-\mathrm{C}(4)-\mathrm{C}(7)$ & $117.4(2)$ & $\mathrm{O}(1)-\mathrm{C}(7)-\mathrm{C}(4)$ & $116.3(2)$ \\
\hline$C(6)^{\# 3}-C(5)-C(4)$ & $118.5(2)$ & $\mathrm{O}(2)-\mathrm{C}(7)-\mathrm{C}(4)$ & $120.7(2)$ \\
\hline C(5)-C(4)-C(7) & $123.1(2)$ & $\mathrm{O}(3)-\mathrm{C}(8)-\mathrm{O}(4)$ & $123.5(2)$ \\
\hline$C(6)^{\# 3}-C(5)-C(8)$ & 117.1(2) & $\mathrm{O}(3)-\mathrm{C}(8)-\mathrm{C}(5)$ & $117.2(2)$ \\
\hline C(4)-C(5)-C(8) & $124.3(2)$ & $\mathrm{O}(4)-\mathrm{C}(8)-\mathrm{C}(5)$ & $119.2(2)$ \\
\hline$C(4)-C(6)-C(5)^{\# 3}$ & $121.9(2)$ & & \\
\hline \multicolumn{4}{|l|}{ Anion II } \\
\hline $\mathrm{C}(9)-\mathrm{C}(10)$ & $140.4(3)$ & $\mathrm{C}(12)-\mathrm{O}(5)$ & $125.1(3)$ \\
\hline $\mathrm{C}(9)-\mathrm{C}(11)$ & $138.6(3)$ & $\mathrm{C}(12)-\mathrm{O}(6)$ & $126.7(3)$ \\
\hline$C(10)-C(11)$ & $138.6(3)$ & $\mathrm{C}(13)-\mathrm{O}(7)$ & $122.7(3)$ \\
\hline $\mathrm{C}(10)-\mathrm{C}(13)$ & $150.7(3)$ & $\mathrm{C}(13)-\mathrm{O}(8)$ & $128.9(3)$ \\
\hline $\mathrm{C}(9)-\mathrm{C}(12)$ & $151.2(3)$ & & \\
\hline $\mathrm{C}(11)^{\# 4}-\mathrm{C}(9)-\mathrm{C}(10)^{\# 5}$ & $119.0(2)$ & $\mathrm{O}(5)-\mathrm{C}(12)-\mathrm{O}(6)$ & $126.0(2)$ \\
\hline $\mathrm{C}(10)^{\# 5}-\mathrm{C}(9)-\mathrm{C}(12)$ & $122.2(2)$ & $\mathrm{O}(5)-\mathrm{C}(12)-\mathrm{C}(9)$ & $119.2(2)$ \\
\hline $\mathrm{C}(11)^{\# 4}-\mathrm{C}(9)-\mathrm{C}(12)$ & $118.7(2)$ & $\mathrm{O}(6)-\mathrm{C}(12)-\mathrm{C}(9)$ & $114.7(2)$ \\
\hline$C(11)-C(10)-C(9)^{\# 6}$ & $119.2(2)$ & $\mathrm{O}(7)-\mathrm{C}(13)-\mathrm{O}(8)$ & $123.5(2)$ \\
\hline $\mathrm{C}(11)-\mathrm{C}(10)-\mathrm{C}(13)$ & $117.9(2)$ & $\mathrm{O}(7)-\mathrm{C}(13)-\mathrm{C}(10)$ & $120.2(2)$ \\
\hline$C(9)^{\# 6}-C(10)-C(13)$ & $122.7(2)$ & $\mathrm{O}(8)-\mathrm{C}(13)-\mathrm{C}(10)$ & 116.1(2) \\
\hline $\mathrm{C}(9)^{\# 4}-\mathrm{C}(11)-\mathrm{C}(10)$ & $121.8(2)$ & & \\
\hline \multicolumn{4}{|c|}{ Hexane-1,6-diammonium-cation } \\
\hline $\mathrm{N}-\mathrm{C}(1)$ & $149.0(4)$ & $\mathrm{C}(2)-\mathrm{C}(3)$ & $152.0(4)$ \\
\hline $\mathrm{C}(1)-\mathrm{C}(2)$ & $150.5(4)$ & $C(3)-C(3)^{\# 2}$ & $151.7(6)$ \\
\hline $\mathrm{N}-\mathrm{C}(1)-\mathrm{C}(2)$ & $112.2(2)$ & $C(3)^{\# 1}-C(3)-C(2)$ & $113.0(3)$ \\
\hline$C(1)-C(2)-C(3)$ & $112.2(3)$ & & \\
\hline
\end{tabular}

\#1: -x;-y;-z , \#2: -x;-y-1;-z-1, \#3: -x;-y;-z-1, \#4: -x+1;-y+1;-z, \#5: x+1;y;z, \#6: $\mathrm{x}-1 ; \mathrm{y} ; \mathrm{z}$
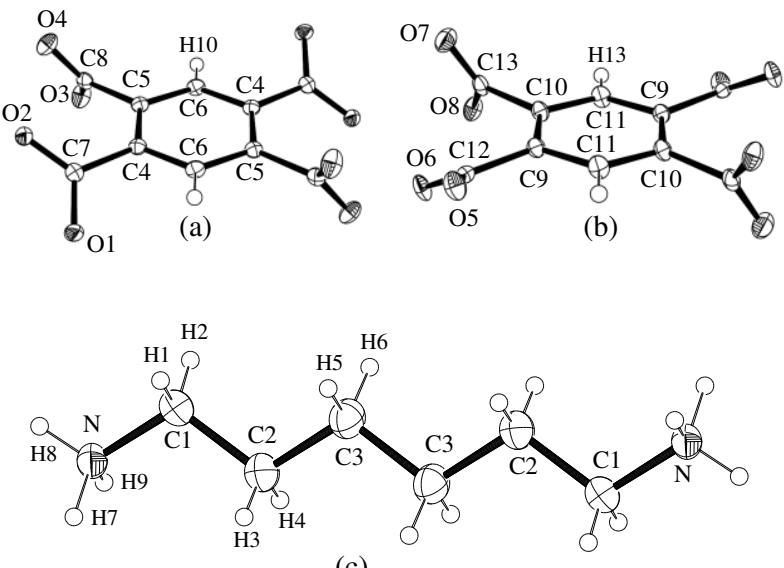

(c)

Figure 2. The $\left[\mathrm{C}_{6} \mathrm{H}_{2}(\mathrm{COO})_{4}\right]^{4-}$ anions I (a) and II (b) as well as the hexane-1,6-diammonium-cation (c) in $\mathbf{1}(50 \%$ probability ellipsoids, arbitrary radii for hydrogen atoms). 
The connection between the $\mathrm{Cu}(2)$-cations and the $\left[\mathrm{C}_{6} \mathrm{H}_{2}(\mathrm{COO})_{4}\right]^{4-}$ anions results in a three-dimensional zeolite-like framework with channel-like voids extending along [100] (Fig. 3 and 4), whereas the coordination between the $\mathrm{Cu}(1)$-cations and the $\left[\mathrm{C}_{6} \mathrm{H}_{2}(\mathrm{COO})_{4}\right]^{4-}$ anions only leads to a stabilization of the structure by lowering the negative charge of the framework. The oxygen atoms of the carboxylate groups coordinate only in a monodentate manner. The diagonals as the largest and narrowest openings of the channel-like voids are approximately $900 \mathrm{pm}$ and 300 $\mathrm{pm}$, respectively, with the van-der-Waals radii [40] of the framework atoms taken into account. The voids are occupied by water molecules not bound to $\mathrm{Cu}^{2+}$ and $\left[\left(\mathrm{CH}_{2}\right)_{6}\left(\mathrm{NH}_{3}\right)_{2}\right]^{2+}$-cations, which compensate for the negative excess charge of the $\left\{\left(\mathrm{Cu}\left(\mathrm{H}_{2} \mathrm{O}\right)\right)_{2} \mathrm{Cu}\left(\mathrm{H}_{2} \mathrm{O}\right)_{2}\left[\mathrm{C}_{6} \mathrm{H}_{2}(\mathrm{COO})_{4}\right]_{2}\right\}_{n}{ }^{2 \mathrm{n}-}$ framework. The $\left[\left(\mathrm{CH}_{2}\right)_{6}\left(\mathrm{NH}_{3}\right)_{2}\right]^{2+}$-cations adopt an antiperiplanar conformation and are located on a crystallographic inversion centre (Fig. 2). The $\mathrm{C}-\mathrm{C}$ bond lengths range from 150.4(4) to $152.0(4) \mathrm{pm}$ and the $\mathrm{C}(1)-\mathrm{N}$ bond is slightly shorter (149.0(4) pm).

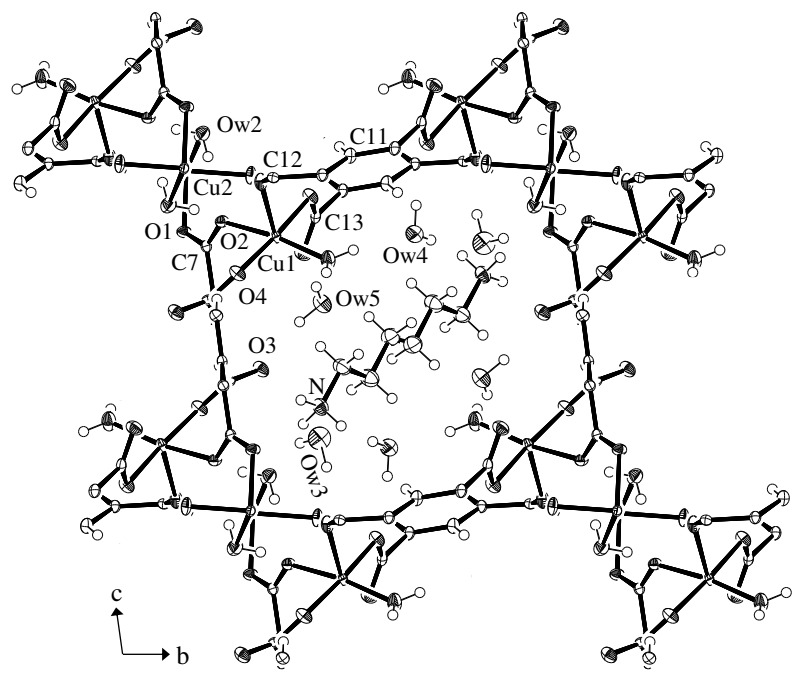

Figure 3. The crystal structure of $\mathbf{1}$ viewed from [100] showing centrosymmetric channel-like voids $(50 \%$ probability ellipsoids, arbitrary radii for hydrogen atoms).

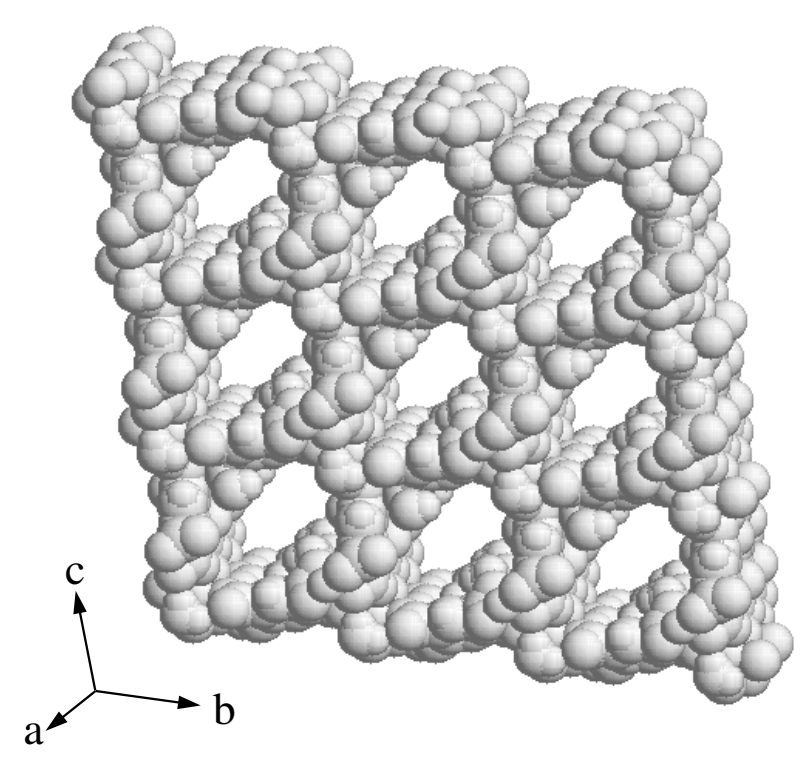

Figure 4. Space filling model of $\mathbf{1}$ (hexane-1,6-diammoniumcations and guest water molecules are omitted).

The water molecules $(\mathrm{O}(\mathrm{w} 3), \mathrm{O}(\mathrm{w} 4)$ and $\mathrm{O}(\mathrm{w} 5))$ which are not connected to $\mathrm{Cu}^{2+}$ serve to stabilize the crystal structure by hydrogen bonds. The $\mathrm{NH}_{3}{ }^{+}$groups of the 1,6diammoniumhexane-cations act as proton donors for $\mathrm{O}(\mathrm{w} 4)$ and the carboxylate oxygen atoms $\mathrm{O}(1)$ and $\mathrm{O}(3)$. With exception of $\mathrm{O}(6)$ all carboxylate oxygen atoms are involved in hydrogen bonds as proton acceptors. The $\mathrm{O} \cdots \mathrm{O}$ distances range from 258.9 to $302.2 \mathrm{pm}$ indicating rather strong hydrogen bonding besides hydrogen bonds of smaller strength [41,42] (Tab. 3).

Table 3. Hydrogen bonds in $\mathbf{1}$

\begin{tabular}{llll}
\hline $\mathrm{N} \cdots \mathrm{O}$ Distance $(\mathrm{pm})$ & & & \\
\hline $\mathrm{N}-\mathrm{H}(7) \cdots \mathrm{O}(1)$ & 287.7 & $\mathrm{~N}-\mathrm{H}(9) \cdots \mathrm{O}(\mathrm{w} 4)$ & 295.5 \\
$\mathrm{~N}-\mathrm{H}(8) \cdots \mathrm{O}(3)$ & 283.7 & & \\
\hline $\mathrm{O} \cdots \mathrm{O}$ Distance $(\mathrm{pm})$ & & & \\
\hline $\mathrm{O}(\mathrm{w} 2)-\mathrm{H}(21) \cdots \mathrm{O}(4)$ & 302.2 & $\mathrm{O}(\mathrm{w} 5)-\mathrm{H}(52) \cdots \mathrm{O}(3)$ & 276.8 \\
$\mathrm{O}(\mathrm{w} 2)-\mathrm{H}(21) \cdots \mathrm{O}(5)$ & 287.8 & $\mathrm{O}(\mathrm{w} 1)-\mathrm{H}(11) \cdots \mathrm{O}(\mathrm{w} 5)$ & 258.9 \\
$\mathrm{O}(\mathrm{w} 2)-\mathrm{H}(22) \cdots \mathrm{O}(2)$ & 276.8 & $\mathrm{O}(\mathrm{w} 1)-\mathrm{H}(12) \cdots \mathrm{O}(\mathrm{w} 4)$ & 274.4 \\
$\mathrm{O}(\mathrm{w} 3)-\mathrm{H}(31) \cdots \mathrm{O}(5)$ & 286.8 & $\mathrm{O}(\mathrm{w} 3)-\mathrm{H}(32) \cdots \mathrm{O}(\mathrm{w} 2)$ & 289.1 \\
$\mathrm{O}(\mathrm{w} 4)-\mathrm{H}(42) \cdots \mathrm{O}(8)$ & 278.9 & $\mathrm{O}(\mathrm{w} 4)-\mathrm{H}(41) \cdots \mathrm{O}(\mathrm{w} 3)$ & 275.5 \\
$\mathrm{O}(w 5)-\mathrm{H}(51) \cdots \mathrm{O}(7)$ & 276.1 & & \\
\hline
\end{tabular}

1 loses water of crystallization upon storage in a desiccator over sulphuric acid yielding a trihydrate (molecular weight 458.62). The elemental analysis yields $\mathrm{C}$ : $34.44 \%, \mathrm{H}: 3.72 \%$, and $\mathrm{N}: 2.94 \%$, which agree very well with the expected values for a trihydrate $(\mathrm{C}: 34.05 \%, \mathrm{H}$ : $3.74 \%$, N: $3.05 \%$.) The single crystals decayed to small pieces which could be rehydrated to the pentahydrate when stored in humid atmosphere. The rehydrated pentahydrate showed the same X-Ray powder diffraction pattern as the starting material (Fig. 5). The elemental analysis confirmed also the formation of a pentahydrate (molecular weight 
494.62; exp./calc.: C: $31.45 / 31.57 \%, \mathrm{H}: 4.18 / 4.28 \%, \mathrm{~N}$ : $2.66 / 2.83 \%$ ).

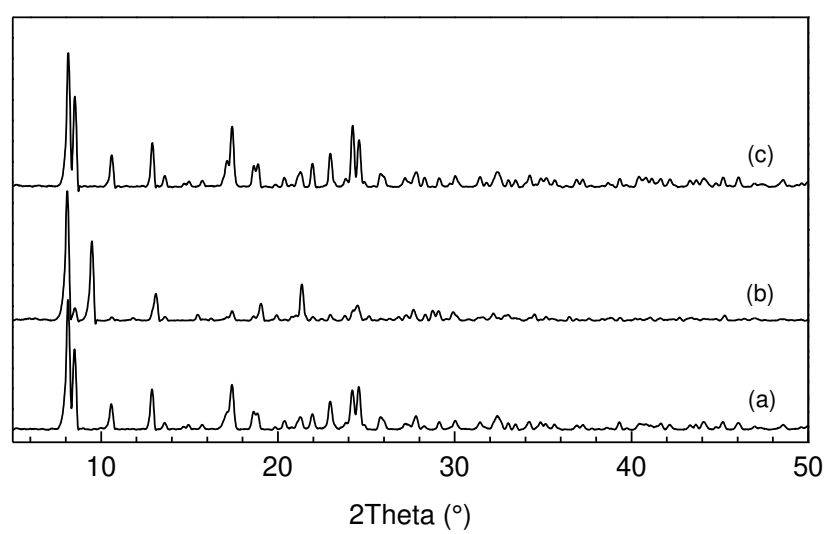

Figure 5: X-ray powder diffraction patterns of 1 (a), dehydrated sample (trihydrate) (b), and rehydrated sample (pentahydrate) (c).

$\mathrm{Si}$ et al. [43] reported on three-dimensional framework in a copper benzene-1,2,4,5-tetracarboxylate accommodating piperidine molecules. However, this compound features chains made up from $\mathrm{Cu}^{2+}$ and $\left[\mathrm{C}_{6} \mathrm{H}_{2}(\mathrm{COOH})_{2}(\mathrm{COO})_{2}\right]^{2-}$ which are cross-linked by solely hydrogen bonds to $\mathrm{H}_{2} \mathrm{O}$ and uncoordinated benzene-1,2,4,5-tetracarboxylic acid.

$\mathrm{Cu}_{2}\left(\mathrm{H}_{3} \mathrm{~N}-\left(\mathrm{CH}_{2}\right)_{6}-\mathrm{NH}_{3}\right)_{0.5}(\mathrm{OH})\left[\mathrm{C}_{6} \mathrm{H}_{2}(\mathrm{COO})_{4}\right] \cdot 3 \mathrm{H}_{2} \mathrm{O}$, (2). There are two crystallographically independent $\mathrm{Cu}^{2+}$-ions occupying general positions of space group $\mathrm{P} 2 / \mathrm{c} . \mathrm{Cu}(1)$ is coordinated in a distorted square pyramidal fashion by three carboxylate oxygen atoms $(\mathrm{O}(4), \mathrm{O}(6), \mathrm{O}(8))$ and twice by $\mathrm{O}(9)$ stemming from hydroxo groups. Two coordination polyhedra of $\mathrm{Cu}(1)$ correlated by a crystallographic inversion center are linked by a common edge $(2 \mathrm{x} \mathrm{O}(9))$ yielding a short $\mathrm{Cu}(1)-\mathrm{Cu}(1)$ contact of 291.76(8) pm. Recently, Mihalcea et al. [44] reported on similar bridging of metal centres by hydroxo groups in uranyl benzene1,2,4,5-tetracarboxylato complexes. The $\mathrm{Cu}(2)$ cation is surrounded in a distorted trigonal bipyramidal manner by four carboxylate oxygen atoms $(\mathrm{O}(1), \mathrm{O}(3), \mathrm{O}(5), \mathrm{O}(7))$ and one hydroxo oxygen atom $(\mathrm{O}(9)$, Tab. 4). The bond angels $\mathrm{O}(5)-\mathrm{Cu}(2)-\mathrm{O} 3$ and $\mathrm{O}(7)-\mathrm{Cu}(2)-\mathrm{O}(5)$ deviate from $120^{\circ}$ considerably. $\mathrm{O}(9)$ is a common corner of the coordination polyhedra of $\mathrm{Cu}(1)$ and $\mathrm{Cu}(2)$ (Fig. 6). Employing the method of Trömel [38,39] the bond order is calculated to $2.20(\mathrm{Cu}(1))$ and $1.94(\mathrm{Cu}(2))$, respectively. Chiang et al. [45] reported on a similar hydroxo-bridged tetranuclear unit in a cobalt benzene-1,2,4,5-tetracarboxylate.

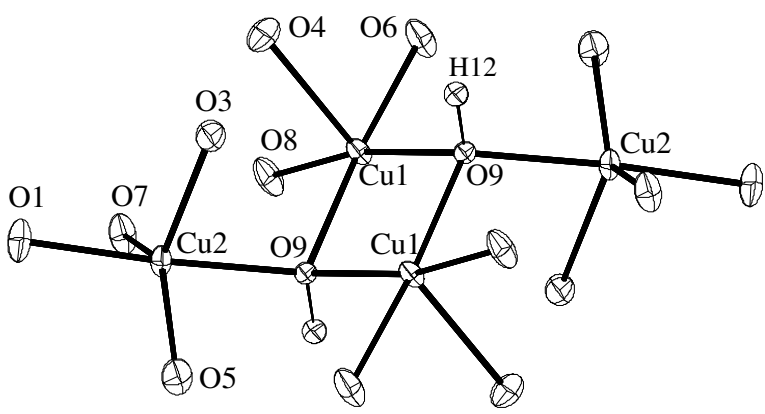

Figure 6. The coordination environments of $\mathrm{Cu}^{2+}$ in 2 (Ellipsoids are given at $50 \%$ probability).

There are also two crystallographically independent $\left[\mathrm{C}_{6} \mathrm{H}_{2}(\mathrm{COO})_{4}\right]^{4-}$ anions. The bond lengths and bond angles are comparable to those of the anions in compound $\mathbf{1}$. The centrosymmetric anion I is almost planar with respect to the carbon skeleton. The largest deviation from a plane fitted to the carbon atoms is $5.4 \mathrm{pm}$ (C6). The carboxylate groups are twisted against the $\mathrm{C}_{6}$-ring by $25.8^{\circ}((\mathrm{C}(7), \mathrm{O}(1), \mathrm{O}(2))$ and $66.5^{\circ}(\mathrm{C}(8), \mathrm{O}(3), \mathrm{O}(4))$, respectively. The $\mathrm{C}-\mathrm{O}$ bond lengths range from $123.6(5)$ to $127.1(5) \mathrm{pm}$. The shortest $\mathrm{C}-\mathrm{O}$ bond is formed by $\mathrm{O}(2)$ which is not connected to $\mathrm{Cu}^{2+}$. The carbon skeleton of anion II which has $\mathrm{C}_{2}$ symmetry is planar with a largest out of plane deviation of $3.3 \mathrm{pm}$ for $\mathrm{C}(11)$. All oxygen atoms from this anion are involved in the $\mathrm{Cu}^{2+}$ coordination. The carboxylate groups show torsions angles of $49.0(\mathrm{C}(12), \mathrm{O}(5), \mathrm{O}(6))$ and $46.5^{\circ}(\mathrm{C}(13), \mathrm{O}(7)$, $\mathrm{O}(8)$ ) with respect to the $\mathrm{C}_{6}$-ring. The variation of the $\mathrm{C}-\mathrm{O}$ bond lengths between 124.2 (7) and 127.1(4) pm is related with the corresponding $\mathrm{Cu}-\mathrm{O}$ bond lengths.

The monodentate coordination between the benzene1,2,4,5-tetracarboxylate anions and the $\mathrm{Cu}^{2+}$-cations builds up a three-dimensional framework with large channel-like voids along [001] (Fig. 7 and 8). The square-like crossection of the channels has a diagonal of $900 \mathrm{pm}$ with the van-derWaals radii [40] of the framework atoms taken into account. The channels accommodate water molecules not bound to $\mathrm{Cu}^{2+}$ and hexane-1,6-diammonium-cations compensating for the negative excess charge of the framework. Analogous to 1 the centrosymmetric hexane-1,6-diammonium-cations are in antiperiplanar conformation. The terminal nitrogen atoms, however, show a small deviation $(7.6 \mathrm{pm})$ from a plane fitted to the $\left[\mathrm{N}-\mathrm{C}_{6}-\mathrm{N}\right]^{2+}$ chain. The $\mathrm{C}(1)-\mathrm{N}$ bond length is 148.3(8) and the $\mathrm{C}-\mathrm{C}$ bonds range from $149.7(11) \mathrm{pm}$ to 153.5 (11) pm. 
Table 4. The Coordination of $\mathrm{Cu}^{2+}$ in $\mathrm{Cu}_{2}\left(\mathrm{H}_{3} \mathrm{~N}-\left(\mathrm{CH}_{2}\right)_{6-}\right.$ $\left.\mathrm{NH}_{3}\right)_{0.5}(\mathrm{OH})\left[\mathrm{C}_{6} \mathrm{H}_{2}(\mathrm{COO})_{4}\right] \cdot 3 \mathrm{H}_{2} \mathrm{O}(\mathbf{2})$

\begin{tabular}{|c|c|c|c|c|}
\hline \multicolumn{5}{|c|}{ bond lengths (pm) } \\
\hline $\mathrm{Cu}(1)-\mathrm{O}(6)$ & & $2.3(3)$ & $\mathrm{Cu}(2)-\mathrm{O}(9)$ & $191.7(2)$ \\
\hline $\mathrm{Cu}(1)-\mathrm{O}(9)$ & & $4.5(2)$ & $\mathrm{Cu}(2)-\mathrm{O}(7)$ & $203.4(3)$ \\
\hline $\mathrm{Cu}(1)-\mathrm{O}(4)$ & & $7.5(2)$ & $\mathrm{Cu}(2)-\mathrm{O}(3)$ & $223.0(3)$ \\
\hline $\mathrm{Cu}(1)-\mathrm{O}(8)$ & & $2.5(3)$ & $\mathrm{Cu}(2)-\mathrm{O}(1)$ & 192.9(2) \\
\hline $\mathrm{Cu}(1)-\mathrm{Cu}(1)^{\#}$ & & $1.76(8)$ & $\mathrm{Cu}(2)-\mathrm{O}(5)$ & 206.1(3) \\
\hline \multicolumn{5}{|c|}{ bond angles $\left({ }^{\circ}\right)$} \\
\hline $\mathrm{O}(6)-\mathrm{Cu}(1)-\mathrm{O}(8$ & & $88.53(11)$ & $\mathrm{O}(9)-\mathrm{Cu}(2)-\mathrm{O}(7)$ & $89.56(10)$ \\
\hline $\mathrm{O}(8)-\mathrm{Cu}(1)-\mathrm{O}(9$ & & $167.86(11)$ & $\mathrm{O}(9)-\mathrm{Cu}(2)-\mathrm{O}(5)$ & $91.60(10)$ \\
\hline $\mathrm{O}(8)-\mathrm{Cu}(1)-\mathrm{O}(9$ & & $92.45(10)$ & $\mathrm{O}(7)-\mathrm{Cu}(2)-\mathrm{O}(5)$ & $143.29(11)$ \\
\hline $\mathrm{O}(6)-\mathrm{Cu}(1)-\mathrm{O}(4$ & & $89.51(11)$ & $\mathrm{O}(1)-\mathrm{Cu}(2)-\mathrm{O}(3)$ & $87.82(11)$ \\
\hline $\mathrm{O}(9)-\mathrm{Cu}(1)-\mathrm{O}(4$ & & $89.63(10)$ & $\mathrm{O}(5)-\mathrm{Cu}(2)-\mathrm{O}(3)$ & $93.30(11)$ \\
\hline $\mathrm{O}(6)-\mathrm{Cu}(1)-\mathrm{O}(9$ & & $94.96(10)$ & $\mathrm{O}(9)-\mathrm{Cu}(2)-\mathrm{O}(1)$ & $175.12(11)$ \\
\hline $\mathrm{O}(6)-\mathrm{Cu}(1)-\mathrm{O}(9$ & & $175.43(11)$ & $\mathrm{O}(1)-\mathrm{Cu}(2)-\mathrm{O}(7)$ & $93.60(11)$ \\
\hline $\mathrm{O}(9)^{\#}-\mathrm{Cu}(1)-\mathrm{O}($ & & $83.18(10)$ & $\mathrm{O}(1)-\mathrm{Cu}(2)-\mathrm{O}(5)$ & $88.08(11)$ \\
\hline $\mathrm{O}(8)-\mathrm{Cu}(1)-\mathrm{O}(4$ & & $102.04(11)$ & $\mathrm{O}(9)-\mathrm{Cu}(2)-\mathrm{O}(3)$ & $87.34(10)$ \\
\hline $\mathrm{O}(9)-\mathrm{Cu}(1)-\mathrm{O}(4$ & & $94.64(10)$ & $\mathrm{O}(7)-\mathrm{Cu}(2)-\mathrm{O}(3)$ & $123.40(11)$ \\
\hline $\mathrm{Cu}(2)-\mathrm{O}(9)-\mathrm{Cu}($ & & $113.45(12)$ & $\mathrm{Cu}(1)^{\#}-\mathrm{O}(9)-\mathrm{Cu}(1)$ & $96.82(10)$ \\
\hline
\end{tabular}
\#: -x;-y+1;-z

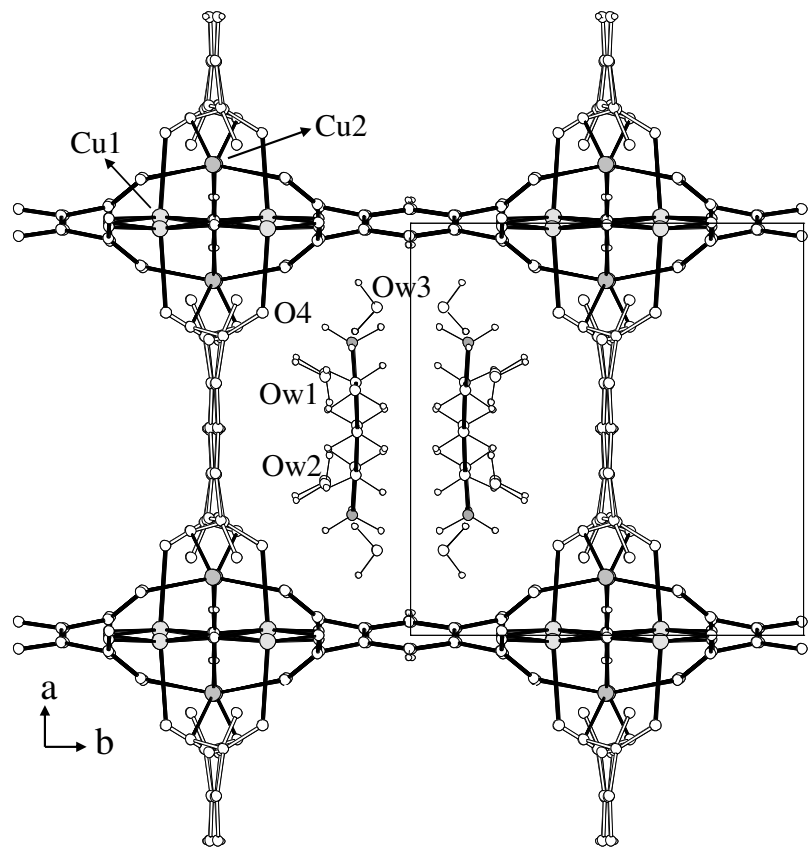

Figure 7. Crystal structure of 2 viewed along [001] showing the square-like channels (50\% probability ellipsoids, arbitrary radii for hydrogen atoms).

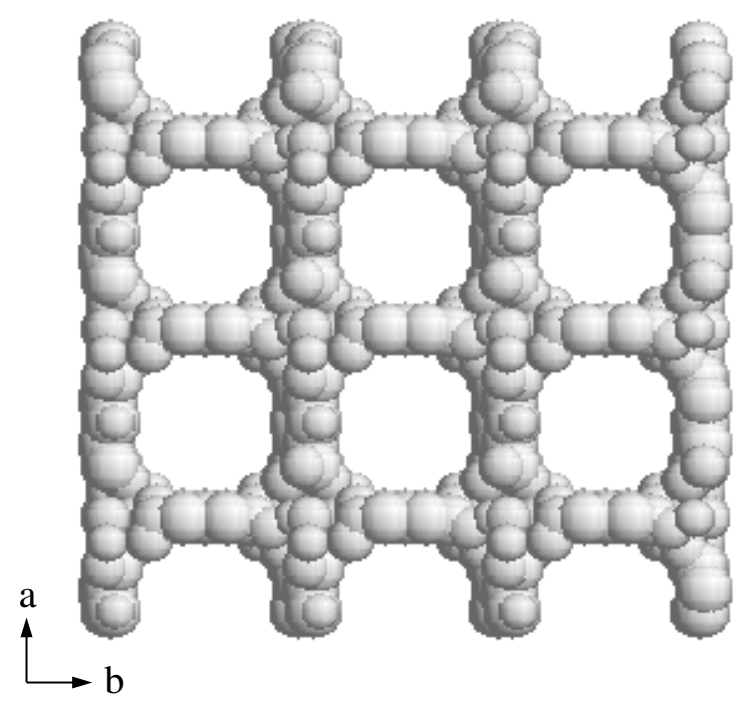

Figure 8. Space filling model of $\mathbf{2}$ (hexane-1,6-diammoniumcations and guest water molecules are omitted).

Table 5. Hydrogen bonds in 2

\begin{tabular}{llll}
\hline $\mathrm{N} \cdots \mathrm{O}$ Distances (pm) & & & \\
\hline $\mathrm{N}-\mathrm{H}(1) \cdots \mathrm{O}(\mathrm{w} 2)$ & 292.1 & $\mathrm{~N}-\mathrm{H}(2) \cdots \mathrm{O}(4)$ & 278.6 \\
$\mathrm{~N}-\mathrm{H}(3) \cdots \mathrm{O}(\mathrm{w} 3)$ & 278.6 & & \\
\hline $\mathrm{O} \cdots \mathrm{O}$ Distances (pm) & & & \\
\hline $\mathrm{O}(9)-\mathrm{H}(12) \cdots \mathrm{O}(2)$ & 256.6 & $\mathrm{O}(\mathrm{w} 1)-\mathrm{H}(13) \cdots \mathrm{O}(\mathrm{w} 2)$ & 289.4 \\
$\mathrm{O}(\mathrm{w} 1)-\mathrm{H}(14) \cdots \mathrm{O}(3)$ & 274.1 & $\mathrm{O}(\mathrm{w} 2)-\mathrm{H}(16) \cdots \mathrm{O}(\mathrm{w} 1)$ & 289.3 \\
$\mathrm{O}(\mathrm{w} 2)-\mathrm{H}(15) \cdots \mathrm{O}(1)$ & 302.8 & $\mathrm{O}(\mathrm{w} 3)-\mathrm{H}(18) \cdots \mathrm{O}(\mathrm{w} 1)$ & 283.8 \\
$\mathrm{O}(\mathrm{w} 3)-\mathrm{H}(17) \cdots \mathrm{O}(8)$ & 286.2 & & \\
\hline
\end{tabular}

Hydrogen bonds between carboxylate oxygen atoms and water molecules contribute to the stabilization of the framework. Except of $\mathrm{O}(5), \mathrm{O}(6)$ and $\mathrm{O}(7)$ the carboxylate oxygen atoms are involved in hydrogen bonds. The oxygen atom $\mathrm{O}(2)$ which is not connected to $\mathrm{Cu}^{2+}$ acts as proton acceptor in a very strong hydrogen bond $(256.6 \mathrm{pm})$ to the hydroxo group $\mathrm{O}(9)-\mathrm{H}(12)$, which coordinated to three $\mathrm{Cu}^{2+}$. $\mathrm{O}(\mathrm{w} 1)$ and $\mathrm{O}(\mathrm{w} 2)$ as well as $\mathrm{O}(\mathrm{w} 1)$ and $\mathrm{O}(\mathrm{w} 3)$ are linked together by hydrogen bonds. The hexane-1,6-diammoniumcation acts as proton donator for $\mathrm{O}(\mathrm{w} 2), \mathrm{O}(\mathrm{w} 3)$ and the carboxylate oxygen atom $\mathrm{O}(4)$ (Tab. 5).

\section{Conclusions}

In summary, we reported on the synthesis and crystal structures of two $\mathrm{Cu}(\mathrm{II})$-benzene-1,2,4,5-tetracarboxylates in the presence of 1,6-diaminohexane as template agent. The connection between the $\mathrm{Cu}^{2+}$-ions and the benzene-1,2,4,5tetracarboxylate-anions leads to three-dimensional frameworks with negative excess charge and channel-like voids. The voids accommodate hexane-1,6-diammoniumcations and water molecules, which are not connected to $\mathrm{Cu}^{2+}$. 


\section{Experimental Section}

Single crystals of $\mathrm{Cu}_{1.5}\left(\mathrm{H}_{3} \mathrm{~N}-\left(\mathrm{CH}_{2}\right)_{6}-\mathrm{NH}_{3}\right)_{0.5}\left[\mathrm{C}_{6} \mathrm{H}_{2}(\mathrm{COO})_{4}\right] \cdot 5 \mathrm{H}_{2} \mathrm{O}$ (1) and $\mathrm{Cu}_{2}\left(\mathrm{H}_{3} \mathrm{~N}-\left(\mathrm{CH}_{2}\right)_{6}-\mathrm{NH}_{3}\right)_{0.5}(\mathrm{OH})\left[\mathrm{C}_{6} \mathrm{H}_{2}(\mathrm{COO})_{4}\right] \cdot 3 \mathrm{H}_{2} \mathrm{O}$ (2) were synthesized in the presence of 1,6-diaminohexane. An aqueous solution of $5 \mathrm{ml} 0.1 \mathrm{M} \mathrm{Cu}\left(\mathrm{NO}_{3}\right)_{2}$ was added to a solution of $5 \mathrm{ml} 0.2 \mathrm{M}$ 1,6-diaminohexane. A precipitate, which appeared intermediately, was dissolved by addition of a small amount of $2 \mathrm{M}$ $\mathrm{HNO}_{3}$. Then a solution of $5 \mathrm{ml} 0.05 \mathrm{M}$ sodium benzene-1,2,4,5tetracarboxylate and $0.2 \mathrm{~g}$ urea were added. For 1, the resulting solution was heated at $55^{\circ} \mathrm{C}$ for 3 days in a drying oven yielding light-blue crystals. To obtain compound $\mathbf{2}$, the solution was heated at $80^{\circ} \mathrm{C}$ for $48 \mathrm{~h}$ resulting in turquoise crystals. In contrast to the synthesis at $55^{\circ} \mathrm{C}$, during the reaction at $80^{\circ} \mathrm{C}$ we observed a significant increase of the $\mathrm{pH}$-value due the decomposition of urea. Results of elemental analyses: 1: (molecular weight 494.62) C 31.39 (calc. 31.57); H 4.28 (4.50); N 2.83 (2.78)\%. 2: (molecular weight 507.36) C 30.03 (30.78); H 3.65 (3.58); N 2.72 (2.76)\%.

IR-ATR $\left(\mathrm{cm}^{-1}\right)$ : 1: 3448(m), 3295(m), 3099(m), 3036(w), 2946(w), 1673(w), 1598(s), 1599(s), 1489(s), 1367(s), 1325(s), 1277((m), 1133(s), 1049(w), 943(m), 919(m), 874(m), 831(m), 812(m), 765(m), 669(s), 617(m). 2: 3445(m), 3238(w), 3182(m), 3058(w), 2960(w), 2873(w), 1679(w), 1630(w), 1574(s), 1492(s), 1426(m), 1376(s), 1323(s), 1289(m), 1141(m), 1108(m), 1040(m), 932(m), 867(m), 816(s), 763(m), 667(m), 611(s).

The TGA/DTA studies (Fig. 9) were carried out in air from room temperature to $1000^{\circ} \mathrm{C}$ at a heating rate of $10 \mathrm{~K} / \mathrm{min}$ using a Netzsch STA-429 device. With 1, a sharp endothermic process between $161^{\circ} \mathrm{C}$ and $180{ }^{\circ} \mathrm{C}$ caused a weight loss of $17.8 \%$, corresponding to the loss of the water molecules. The dehydrated compound was stable up to $250{ }^{\circ} \mathrm{C}$. Several exothermic decomposition processes up to $1000{ }^{\circ} \mathrm{C}$ caused a total weight loss of $79.3 \%$. With 2 , an endothermic weight loss between 100 and $230^{\circ} \mathrm{C}(10.2 \%)$ corresponds to the loss of all water molecules followed by a further weight loss of $3.4 \%$ up to $260{ }^{\circ} \mathrm{C}$, which can be associated to the removal of water stemming from dehydroxylation of $\mathrm{OH}$-groups. The following decomposition processes up to $1000{ }^{\circ} \mathrm{C}$ of the dehydrated sample caused a total weight loss of $75.1 \%$. The residue in both cases contained $\mathrm{Cu}_{2} \mathrm{O}$ and $\mathrm{CuO}$ which were identified by $\mathrm{X}$-ray powder diffraction.

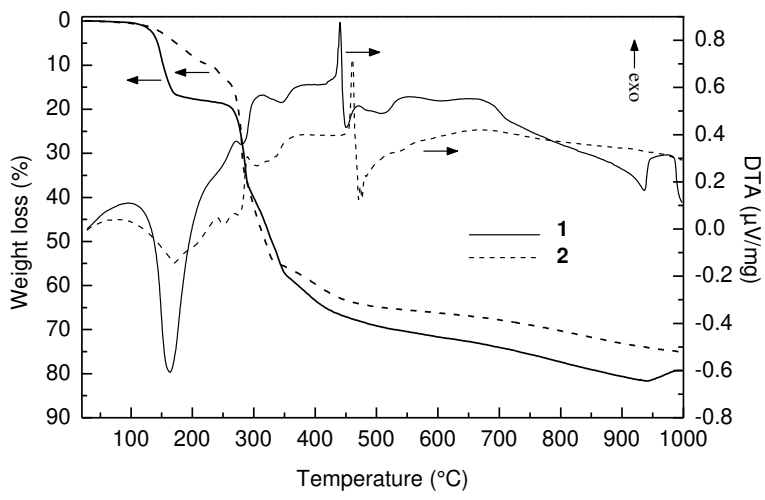

Fig. 9: Thermal analysis of compound $\mathbf{1}$ and $\mathbf{2}$.

ATR Fourier transformed infrared (IR-ATR) measurements were carried out at room temperature using a Bio-rad FTS 25. X-Ray powder diffraction patterns were collected at room temperature on a Siemens D5000 ( $\mathrm{CuK} \alpha$, germanium monochromator). X-ray single crystal structure determination was performed on a Siemens $\mathrm{P} 4$ four-circle diffractometer (MoK $\alpha$, graphite monochromator) in a theta range up to $25.00^{\circ}$. Numerical absorption corrections have been applied. Extinction effects have been compensated for by introduction of an extinction parameter. The phase problem was solved by direct methods. Full matrix least squares refinement employing $\mid \mathrm{F}^{2}$ made use of the SHELXTL program suite [46]. Difference Fourier maps revealed the positions of all hydrogen atoms. They were allowed to refine individually with different common isotropic displacement parameters. Crystallographic data are given in Table 6.

Further details concerning the crystal structure analyses have been deposited with Cambridge Crystallographic Data Centre, The Director, CCDC, 12 Union Road, Cambridge CB21EZ, UK, Fax +(1223)336-033, e-mail data_request@ccdc.cam.ac.uk, www.ccdc.cam.ac.uk/data_request.cif under CCDC 941917 and CCDC 941918.

Table 6. Crystallographic Data

\begin{tabular}{|c|c|c|}
\hline & 1 & 2 \\
\hline Empirical formula & $\begin{array}{l}\mathrm{C}_{13} \mathrm{H}_{21} \mathrm{NCu}_{1.5} \mathrm{O}_{13} \\
\text { triclinic }\end{array}$ & $\begin{array}{l}\mathrm{C}_{13} \mathrm{H}_{18} \mathrm{NCu}_{2} \mathrm{O}_{12} \\
\text { moclinic }\end{array}$ \\
\hline Space group & P-1 (no.2) & $\mathrm{P} 2 / \mathrm{c}($ no. 13$)$ \\
\hline \multirow[t]{6}{*}{ Lattice constants } & $\mathrm{a}=772.56(7) \mathrm{pm}$ & $\mathrm{a}=1159.34(11) \mathrm{pm}$ \\
\hline & $\mathrm{b}=1110.36(7) \mathrm{pm}$ & $\mathrm{b}=1059.44(7) \mathrm{pm}$ \\
\hline & $\mathrm{c}=1111.98(8) \mathrm{pm}$ & $\mathrm{c}=1582.2(2) \mathrm{pm}$ \\
\hline & $\alpha=98.720(7)^{\circ}$ & $\beta=106.130(11)^{\circ}$ \\
\hline & $\beta=108.246(9)^{\circ}$ & \\
\hline & $\gamma=95.559(7)^{\circ}$ & \\
\hline Cell volume & $0.88480(12) \mathrm{nm}^{3}$ & $1.8669(3) \mathrm{nm}^{3}$ \\
\hline Formulas in unit cell & 2 & 4 \\
\hline Formula weight & $494.62 \mathrm{~g} / \mathrm{mol}$ & $507.36 \mathrm{~g} / \mathrm{mol}$ \\
\hline Density (calc.) & $1.857 \mathrm{~g} / \mathrm{cm}^{3}$ & $1.805 \mathrm{~g} / \mathrm{cm}^{3}$ \\
\hline Wavelength & \multicolumn{2}{|c|}{$71.073 \mathrm{pm}$} \\
\hline Absorption & $1.893 \mathrm{~mm}^{-1}$ & $2.342 \mathrm{~mm}^{-1}$ \\
\hline \multicolumn{3}{|l|}{ coefficient } \\
\hline numerical & $\min . / \max$. & $\min . / \max$ \\
\hline Absorption & transmittance & transmittance \\
\hline correction & $0.644 / 0.895$ & $0.747 / 0.778$ \\
\hline Temperature & \multicolumn{2}{|c|}{$293(2) \mathrm{K}$} \\
\hline Crystal size (mm) & $0.06 \times 0.26 \times 0.48$ & $0.14 \times 0.14 \times 0.46$ \\
\hline $\mathrm{F}(000)$ & 507 & 1028 \\
\hline$\Theta$-range & $2.44^{\circ}-25.00^{\circ}$ & $2.34^{\circ}-24.99^{\circ}$ \\
\hline \multirow[t]{2}{*}{ Limiting indices } & $\mathrm{h}-1 /+9 \mathrm{k}-12 /+12$ & $\mathrm{~h}-1 /+13 \mathrm{k}-1 /+12$ \\
\hline & $1-13 /+12$ & $1-18 /+18$ \\
\hline Reflections & 3848 & 4266 \\
\hline collected & & \\
\hline Independent & $3104\left(\mathrm{R}_{\mathrm{int}}=0.0196\right)$ & $3297\left(\mathrm{R}_{\mathrm{int}}=0.0194\right)$ \\
\hline
\end{tabular}

reflections

Structure solution

Structure refinement

Refined parameters

Extinction

Direct methods

parameter

Final mean shift/esd $0.006 \quad 0.006$

Goodness-of-fit on $\quad 1.213 \quad 1.407$

$/ \mathrm{F} /{ }^{2}$

Residuals (all data) $\quad \mathrm{R}_{1}=0.0308, \mathrm{wR}_{2}=\mathrm{R}_{1}=0.0420, \mathrm{wR}_{2}=$ $0.0581 \quad 0.0720$

Max. features in last 322 and $-351 \mathrm{e} \cdot \mathrm{nm}^{-3} \quad 995$ and $-489 \mathrm{e} \cdot \mathrm{nm}^{-3}$ difference Fourier 
24] M. Rafizadeh and F. Manteghi, Acta Cryst. 2009, E65, m17.

\section{Acknowledgement}

We are grateful to Mrs Christina Apfel for recording the thermoanalytical data and the X-ray powder patterns.

\section{References}

[1] G. Férey, Chem. Soc. Rev. 2008, 37, 191-214.

[2] L.-M. Zhao, H.-H. Li, Y. Wu, S.-Y. Zhang, Z.-J. Zhang, W. Shi, P. Cheng, D.-Z. Liao, S.-P. Yan, Eur. J. Inorg. Chem. 2010, 1983-1990.

[3] L. Karanovic, D. Poleti, G.A. Bogdanovic, A. Spasojevic-de Bire, Acta Cryst. 1999, C55, 911-913.

[4] D. Poleti and L. Karanovic, Acta Cryst. 1989, C45, 1716-1718.

[5] D. Poleti, D.R. Stojakovic, B. V. Prelesnik, R.M. Herak, Acto Cryst. 1988, C44, 242-245.

[6] M. Singh, D. Kumar, J. Thomas, A. Ramanan, J. Chem. Sci. 2010, $122,757-769$.

[7] S. Hentschel, Ph.D. Thesis, Univ. Munich 1993.

[8] B. Paul, B. Zimmermann, K.M. Fromm, C. Janiak, Z. Anorg. Allg. Chem. 2004, 630, 1650-1654.

[9] P. Lightfoot and A. Snedden, J. Chem. Soc., Dalton Trans. 1999, 3549-3551.

[10] J. Zhong-Sheng, D. Zhi-Bang, W. Ge-Cheng, N. Jia-Zhan, Jiegou Huaxue (J. Struct. Chem.) 1990, 9, 69-72.

[11] C. Robl , Mat. Res. Bull. 1992, 27, 99-107.

[12] J.-P. Geng, Z.-X. Wang, X. He, H.-P. Xiao, M.-X. Li, Inorg. Chem. Comm. 2011, 14, 997-1000.

[13] Y.-Y. Jia, B. Chen, Y.-X. Yuan, Acta Cryst. 2012, E68, m1150.

[14] J.-C. Yao, Y.-F. Wang, L. Zhang, J.-B. Guo, X.-X. Cao, C.-P. Fan, Chinese J. Struct. Chem. 2011, 30, 170-175.

[15] E. Suresh, K. Boopalan, R.V. Jasra, M.M. Bhadbhade, Inorg. Chem. 2001, 40, 4078-4080.

[16] C. Ma, W. Wang, X. Zhang, C. Chen, Q. Liu, H. Zhu, D. Liao, L. Li, Eur. J. Inorg. Chem. 2004, 3522-3532.

[17] R. Köferstein and C. Robl, Z. Anorg. Allg. Chem. 2005, 631, $1756-1758$

[18] R. Murugavel, D. Krishnamurthy, M. Sathiyendiran, J. Chem. Soc., Dalton Trans. 2002, 34-39.

[19] P.J. Hagrman, D. Hagrman, J. Zubieta, Angew. Chem. 1999 $111,2789-2848$.

[20] M. Rafizadeh, V. Amani, S. Zahiri, Acta Cryst. 2007, E63 m1938.

[21] R. Köferstein and C. Robl, Z. Anorg. Allg. Chem. 2007, 633, $1323-1325$.

[22] A. Majumder, V. Gramlich, G.M. Rosair, S.R. Batten, J.D Masuda, M.S. El Fallah, J. Ribas, J.-P. Sutter, C. Desplanches, S. Mitra, Cryst. Growth Des. 2006, 6, $2355-2368$.

[23] R. Köferstein and C. Robl, Z. Anorg. Allg. Chem. 2004, 630, 185-188.
[25] S. Decurtins, H.W. Schmalle, P. Schneuwly, H.R. Oswald Inorg. Chem. 1993, 32, 1888-1892.

[26] R. Vaidhyanathan, S. Natarajan, A.K. Cheetham, C. Rao, Chem. Mater. 1999, 11, 3636-3642.

[27] R. Vaidhyanathan, S. Natarajan, C. Rao, Chem. Mater. 2001, $13,185-191$

[28] R. Köferstein and C. Robl, Z. Anorg. Allg. Chem. 2003, 629 2186-2189.

[29] S.S. Massoud, F.A. Mautner, F.R. Louka, S. Demeshko, S Dechert, F. Meyer, Inorg. Chim. Acta 2011, 370, 435-443.

[30] Y.Y. Karabach, A.M. Kirillov, M. Haukka, J. Sanchiz, M.N Kopylovich, A.J.L. Pombeiro, Cryst. Growth Des. 2008, 8, 4100-4108.

[31] E.-C Yang, Z.-Y. Liu, Z.-Y. Liu, L.-N. Zhao, X.-J. Zhao, Dalton Trans. 2010, 39, 8868-8871.

[32] H. Lin, H. Hu, X. Wang, B. Mu, J. Li, J. Coord. Chem. 2010 63, 1295-1303

[33] R. Cao, Q. Shi, D. Sun, M. Hong, W. Bi, Y. Zhao, Inorg Chem. 2002, 41, 6161-6168.

[34] D. Poleti, L. Karanovic, J. Serb. Chem. Soc. 2005, 70, $1441-1450$

[35] R. Köferstein and C. Robl, Z. Anorg. Allg. Chem. 2003, 629, 1374-1378.

[36] Y.Y. Karabach, A.M. Kirillov, M. Haukka, M.N. Kopylovich, A.J.L. Pombeiro, J. Inorg. Biochem. 2008, 102, 1190-1194.

[37] S. Marx, W. Kleist, A. Baiker, J. Catal. 2011, 281, 76-87.

[38] M. Trömel, Acta Cryst. 1983, B39, 664-669.

[39 ] M. Trömel, Acta Cryst. 1984, B40, 338-442.

[40] A. Bondi, J. Phys. Chem. 1964, 68, 441-451.

[41] P.A. Kollmann and L.C. Allen, Chem. Rev. 1972, 72, 283-303.

[42] I.D. Brown, Acta Cryst. 1976, A32, 24-31.

[43] S.-F. Si, R.-J. Wang, Y.-D. Li, Inorg. Chem. Comm. 2003, 6, $1152-1555$

[44] I. Mihalcea, N. Henry, C. Volkringer, T. Loiseau, Cryst. Growth Des. 2012, 12, 526-535.

[45] R.-K. Chiang, N.-T. Chuang, C.-S. Wur, M.-F. Chong, C.-R Lin, J. Solid State Chem. 2002, 166, 158-163.

[46] G. M. Sheldrick, Acta Cryst. 2008, A64, 112-122.

Received: ((will be filled in by the editorial staff)) Published online: ((will be filled in by the editorial staff)) 

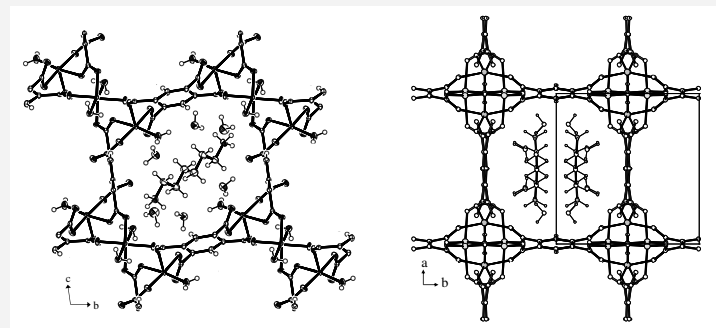

Roberto Köferstein and Christian Robl* Page No. - Page No.

Synthesis and Crystal Structure of two Cu(II)-benzene-1,2,4,5tetracarboxylates with Three-Dimensional Open Frameworks

Two new Cu(II)-benzene-1,2,4,5-tetracarboxylates with 1,6diaminohexane as template agent have been synthesized and structurally characterized. The three-dimensional frameworks show large channel-like voids accommodating water molecules and hexane1,6-diammonium-cations. 